\title{
Enlarged paintings: a proposal for classification
}

\section{Pinturas ampliadas: uma proposta de classificação}

\author{
ANA ISABEL LÓPEZ \\ BONILLA ${ }^{1}$ \\ JOSÉ MANUEL BARROS \\ GARCÍA $^{2, * *}$ (1) \\ SUSANA MARTÍN REY ${ }^{2}$
}

1. Escuela de Arte y Superior de Diseño de Burgos, Burgos, Spain 2. Departamento de

Conservación y Restauración de

Bienes Culturales, Universitat

Politècnica de València,

Valencia, Spain

*jobargar@crbc.upv.es

\begin{abstract}
The concept of enlarged painting refers to the technique of extending the support of an easel painting as well as its compositional space, to simulate a continuity with the original painting. Enlargements of support are considered historical additions with a huge documentary weight, so making decisions about their conservation entails great responsibility. Furthermore, additions can be key for a painting to fulfil its function within a certain social assemblage or network, so to promote correct decision making, it is vital to know the reasons why a painting was enlarged. The aim of this research has been to develop a classification of enlarged paintings, according to the purpose of the enlargement. The classification includes the following categories: updating pictures, adaptation to a new space and/or a new frame, completing mutilated paintings, changes in iconography, enlargement in order to create independent works, and grouping paintings together.
\end{abstract}

\section{Resumo}

O conceito de pintura ampliada refere-se à técnica de aumentar o suporte de uma pintura de cavalete, bem como o seu espaço composicional, para simular uma continuidade com a pintura original. As ampliações de suporte são consideradas acréscimos históricos com um grande peso documental, pelo que a tomada de decisão sobre a sua conservação implica uma grande responsabilidade. Além disso, os acréscimos podem ser fundamentais para que uma pintura cumpra a sua função dentro de uma determinada rede ou montagem social, portanto, para promover uma tomada de decisão correta, é fundamental conhecer os motivos que levaram uma pintura a ser ampliada. O objetivo desta investigação foi desenvolver uma classificação para as pinturas ampliadas, de acordo com a finalidade dessa ampliação. A classificação inclui as seguintes categorias: atualização de imagens, adaptação a um novo espaço e/ou uma nova moldura, conclusão de pinturas mutiladas, mudanças na iconografia, ampliação para criação de obras independentes e agrupamento de pinturas.

\section{PALAVRAS-CHAVE}

Pintura

Ética

Montagem

Conservação

Alteração de forma 


\section{Introduction}

This paper deals with enlarged paintings, that is, paintings whose support has been enlarged in order to increase the dimensions of the pictorial composition and, sometimes, to alter the shape of the support (from a rectangular format to an oval one, for example). From the sixteenth to the nineteenth century, changing the format and composition of paintings (on canvas or panel) was quite a common practice in several European countries such as France, Italy or Spain, even by the painters themselves, who sometimes modified their own works or those of other artists [1].

In France, the Inventaire des tableaux du Roy [2] describes the enlargement of many paintings, as well as the dimensions of the works before and after modification. Vindry [3] estimates that 25 per cent of the paintings from the French royal collections suffered format changes between the sixteenth and eighteenth centuries (as quoted in [4]). In Italy, notable works such as the Madonna of the Baldacchino by Raphael [5], the Pala Pitti by Fra Bartolommeo or the Pala Dei by Rosso Fiorentino [6] were enlarged. In Spain it was also common practice in the collection of Philip IV, where Carducho and Velázquez were in charge of restoration tasks, including enlarging works. Several of Velázquez's paintings, for example, The Spinners, Philip III on Horseback or Mercury and Argus were also enlarged by other painters [7-11].

The painting technique in the enlargement corresponds to that used when the intervention was carried out, usually oil painting [12]. In general, the enlargement process can be divided into the following stages: (a) choosing a new format for the painting; (b) joining the new pieces (by sewing, gluing, etc.) to the original support and strengthening the whole work (with lining, a wooden cradle, etc.); (c) applying a ground layer (if the addition did not have a ground stratum and/or was painted); (d) painting the addition; (e) evening out the colour on new areas, regarding the original painting, by means of overpaints, layers of varnish and/or some kind of artificial patina [13].

However, the aim of this paper is not to analyse the technical aspects of this type of intervention, but rather to put forward a classification of non-original enlargements in a similar way to that carried out by Martin and Bret [14] for the originals. That classification was based on when the enlargement was carried out (for example, when the work was being painted or once it was finished). In this paper, the criterion has been to classify according to the aim soughtafter by the enlargement process.

Despite its importance in the history of painting, enlargement has not been the object of many studies. However, it is particularly important to cite the works of Alessandro Conti [15] and Ségolène Bergeon [16]. These studies have been decisive in the elaboration of this paper, which aims to continue the work initiated by these researchers. The experience of authors on the conservationrestoration of enlarged paintings has also been relevant.
The classification presented in this paper does not presume to be definitive or inflexible, since there are undoubtedly more reasons for enlargement which have not been included. It is indeed quite usual for paintings to be enlarged as a consequence of, not one, but several reasons. On the other hand, it is not always easy to determine whether the transformation observed is the cause or consequence of an enlargement. For example, in an enlarged painting whose meaning has been modified: was the enlargement made with the purpose of modifying the meaning? Or, on the contrary, has the meaning been modified due to the enlargement? These questions are often difficult to answer.

The reason for writing a paper exclusively on enlargements, without including mutilations must also be explained. Both interventions are carried out in order to change a work's dimensions and the aims may be similar (for example, adapting a painting to a new location). A fine example of a work which has suffered both mutilations and enlargements would be that of the three panels by Perugino (The National Gallery, London) from an altarpiece in a Carthusian monastery (Certosa di Pavia) near Milan [17].

However, the problems which arise in either case (mutilations and enlargements) are different. While mutilation is approached as a problem of reintegration, enlargement is tackled as a problem concerning the preservation or removal of non-original additions. Therefore, the most usual questions which arise when dealing with the conservation of an enlarged painting are: Should the additions be removed? Should they be preserved within sight? Or, would it be better to conserve them hidden from view? The reasons behind enlargement, by themselves, can only offer partial answers to these questions as reality tends to be very complex. However, in some cases, this information can prove to be a valuable aid in finding the best solution [16].

\section{Enlarged paintings as assemblages}

Before presenting the classification proposal, based on the reasons why a painting is enlarged, it is necessary to explain the painting's status. That is, whether an enlarged painting should be studied as a new artefact, different from the original, or if it should simply be considered as an original work with additions (and, in this case, whether the additions have any value or not should also be taken into account). Of course, it is quite usual to pose this question when dealing with any painting which has non-original additions [18], but in the case of enlarged paintings, doubts may prove to be very important as modifications could be of great significance, affecting the work's entire structure.

One way of approaching this matter was developed by Cesare Brandi, who presents the question of non-original additions as a problem articulated through the study of aesthetic and historical values the modified work may have, 
and how these values are altered by the additions. Brandi points out that an addition can, in any case, have the value of a historical document, an "evidence of human activity" $[19$, p. 68]. However, Brandi contends that there is a tension between the historical dimension and "the artistic nature of a work of art", so that "if the addition disturbs, perverts, obscures or detracts in part from the sight of the work of art, the addition must be removed" [19, p. 73].

Underlining the tension between aesthetic and historical values is a key contribution of Brandi's thought, although it does, ultimately, grant greater importance to aesthetic values over historical ones, as the former would constitute the true essence of a painting as a work of art. That is, the original work has an artistic value whereas the additions would have a documentary value.

Brandi's attempt to develop a methodology for decisionmaking has had some very positive consequences and contributed to approaching the problem of enlarged paintings in a much less arbitrary way than previously. It has also enabled the design of interesting solutions regarding the exhibition of works $[16,20]$. However, Brandi's theories clearly have a number of limitations, as pointed out by Muñoz Viñas [21-23]. It is important to note here that Brandi's approach is reductionist in character, causing in many cases contradictions between historical and aesthetic values which are almost impossible to solve. Besides, the painting, viewed exclusively as a work of art, appears as a decontextualized artefact, isolated from social use and dynamics.

At present, the tendency is to place cultural artefacts, including paintings and even when these are works of art exhibited in museums, within social dynamics [24-25]. One way of putting forward this social re-placement of cultural artefacts is through assemblage, a term frequently used nowadays by the social sciences [26-28], and which enables a better understanding of the problem of enlarged paintings beyond dualistic thinking (aesthetics/history, art/artefact). In this way, it is possible to study an enlarged painting as a material assemblage and also as part of a social assemblage.

\section{Material assemblage}

An enlarged painting can be understood as a material assemblage which constitutes the work as it is at the present moment: a composition made up of different pieces, from different periods in time, by different people and, usually, with different techniques and materials. So, for example, an enlarged panel painting could be made up of boards of diverse wood species as well as having new crossbars added (Figure 1). In some cases, later additions could even be fragments from another painting. These assemblages generate multiple changes in the work: in the stratigraphic structure, the visual composition and the stability of the materials used.

The union of heterogeneous elements generates a new and complex stratigraphic structure which includes new ground layers, fillers, overpaints and varnish, both in the
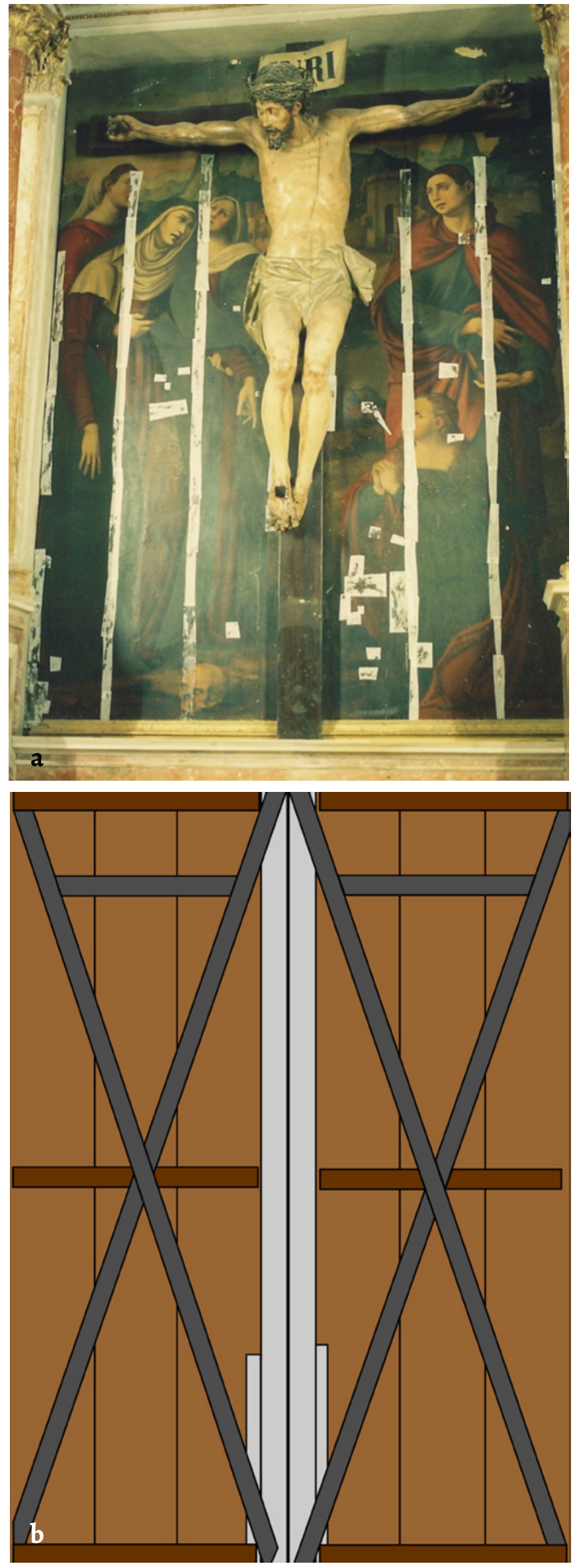

Figure 1. The Crucifixion (16th century, Valencia Cathedral): a) before restoration and $b$ ) back of panels (the additions are shown in light grey and the new crossbars in dark grey). Credits: J. M. Barros García. 
additions and the actual original painting. The assemblage can become extremely complex and difficult to analyse, but it is fundamental to understand the function of the nonoriginal layers in the construction of the resulting work, in order to make decisions regarding its conservation [18].

Incorporating more space produces different alterations to the composition. Some of these modifications include changing the format's orientation (from horizontal to vertical, for example), changing the axis of symmetry, altering the visual weight's disposition and/or altering perspective. More or less obvious differences can also be observed between the original painting technique and that used in the additions (for example, colours, brush-strokes, or texture) [13].

Lastly, the assemblage can be more or less stable from the point of view of its conservation. By joining materials which tend to be quite different, structural problems may ensue. For example, due to the changes in relative humidity, a panel painting could suffer differential shrinkage and swelling of the new boards with regard to the older ones. Gaps between parts of the support (for example, between the boards of a wooden support), or badly designed cradles are also common problems in enlarged panels, and can generate all kinds of structural tensions.

All of these issues are essential and must be taken into account when making decisions regarding whether to preserve or eliminate later additions. However, the enlarged painting cannot be considered just as a material assemblage, it must also be studied as part of a social one.

\section{Social assemblage}

Although an enlarged work can be understood just as a material assemblage, this concept can be used in a broader sense. An enlarged painting (like any other cultural artefact) can be understood as part of a social assemblage. The concept of assemblage can be used starting from the research developed in the Assemblage Theory (AT). At this point, it is relevant to mention also the Actor-Network Theory (ANT), given the similarities of these two theories regarding the topics this paper deals with, in spite of the fact that notable differences do exist in other aspects [29].

The AT was initially put forward by Deleuze and Guattari, particularly in A Thousand Plateaus [30]. Later, researchers like DeLanda [27-28] have developed this theory in a more structured way. To simplify, an assemblage can be defined as "a mode of ordering heterogeneous entities so that they work together for a certain time" [31, p. 27]. On the other hand, the ANT has been developed by Latour [32] and other researchers, for instance, Law, who has made use of elements from both theories [33].

However, it must be pointed out that despite the use of the word theory, they are not actually theories per se, but rather a set of tools for socio-technical analysis which can also be understood as "a sensibility to materiality, relationality, and process" [33, p. 157]. Recently, the AT and the ANT have started to be applied in the field of cultural heritage [34-35]. These tools can help better understand how to plan the study of complex heritage artefacts, in particular those that have been transformed and have gone through diverse social contexts, thereby acquiring new meanings, uses and values.

Both the AT and the ANT put forward a view of social worlds as networks of heterogeneous elements (people, artefacts, non-material entities, etc.) and ever-changing links. An interesting aspect of the ANT, from the conservation of cultural heritage point of view, is that material artefacts can also be considered participants (actants or actors) in networks. Although some controversy arose regarding the active role assigned to the non-human actants (principle of generalized symmetry), Latour later explained this question in more detail [32]. An artefact (for instance, a painting) can be considered an actant or actor provided it modifies "a state of affairs by making a difference” [32, p. 71]. That is to say, a painting's presence must have a significant effect on people and/or their relationships. This is the case of paintings which are enlarged. The enlargement process can be carried out either to maintain a painting's function (for example, a religious purpose deemed worth keeping, even if the context changes) or, on the contrary, its aim can be to completely transform the image.

Müller [31] points out the essential characteristics of assemblages, three of which (also of great importance within the ANT) we will mention here: relationality (the relationships among entities are of great importance, sometimes more so than their properties), heterogeneity (links are established not only among people but also among people and artefacts as well as among the artefacts themselves) and productivity (new assemblages generate new organisations, behaviours and actors).

Relationality implies a painting cannot be analysed out of context, like a work of art which exists only for and by itself. A painting is always located within a context in which multiple relationships exist: with other paintings, with other artefacts in the same space, with the space itself where the painting is on show, with iconographic programmes, with stakeholders or occasional visitors, etc. No matter where the painting is, it is never isolated but linked, one way or another, to people, beliefs and artefacts, that is, to heterogeneous elements.

Productivity means that a new assemblage produces new actors and behaviours (among many other characteristics and elements). For instance, the work may have changed context (for example, from a church to a private collection), or the context itself may have changed (changes in the décor of a palace, for instance). When a painting becomes part of a new assemblage, the artefacts and people linked to the work can change and so too can the new relationships that are generated. For example, when a painting is removed from a religious context and relocated to a museum, people will interact with the work in very different ways.

In each social assemblage, a painting will have diverse values and functions [36] according to the relationships 
established with other elements. By changing the assemblage, it is possible that the painting needs to be adjusted, modifying, among others, its visual composition and iconography, in order to adapt it to the requirements of the new relationships. At present, this means having to decide whether, in the painting's new context, the additions should be eliminated, shown or hidden. One particular addition may make sense in a given social assemblage (for example, making a painting's size the same as others' in order to create a series) but be incongruent in a different one (where the painting is an individual piece).

One of the consequences of seeing a painting as part of a social assemblage is that aesthetic aspects are no longer understood just from an artistic point of view, from the viewpoint of disinterested contemplation. It is possible to link contributions from the anthropology of art to what has been discussed so far concerning assemblages. Alfred Gell's theories, where the art object "is a physical entity which mediates between two beings and therefore creates a social relation between them, which in turn provides a channel for further social relations and influences" [37, pp. 172-173] would be a good example. In this sense, aesthetics refers to the formal characteristics which allow an object to carry out its function [38] in an assemblage. Therefore, when studying an enlarged painting, it is not simply a case of identifying what aesthetic changes have taken place in the picture, but if these allow it to perform its role within the social assemblage it now belongs to.

That is to say (as will be dealt with in the following section), the additions may have altered negatively a painting's formal characteristics from an artistic point of view, yet those additions may be key in enabling the work to comply with its function and maintain its value within a given social assemblage.

\section{Classification of the enlargements}

The classification proposed in this section is based on the main reasons for enlarging a painting. Enlargements are carried out due to the necessity of establishing new relationships such as, for example, between one painting and other paintings, with other artefacts in the exhibition space (as well as with its own space) and with spectators and stakeholders, within changing contexts (new social assemblages).

\section{Updating pictures}

The main aim of these modifications is to update a picture so that it can continue to comply with a certain function within a new assemblage. In this way, the painting is modified in order to adapt it to a new artistic or decorative style. Changes in the ways of relating to a painting have, on many occasions, meant that images have had to be brought up to date (for example, with modifications in composition) so that they could act as required according to the needs of a new context. For example, from the Renaissance, new relationships established with religious paintings demanded that they be more realistic. This caused a need to modify many Gothic paintings, changing their format, overpainting gilt backgrounds with architecture or landscape and/ or modifying the frames. The other categories do not necessarily imply a change in style. For example, regarding adaptation to a new space, grouping or completing mutilated paintings, enlargements can be carried out in the same style as the originals (or as similar to them as possible), without attempting to modernize the images. However, the aim of enlargement in this section is concerned with just that: updating the images [16].

\section{Change of composition}

Any alteration of the work's format, no matter how small, will also modify the composition. However, this section does not focus on the consequences, but instead, on the reasons for enlargement. That is, the main aim of the enlargement would be to modify a painting's composition without altering its format (thus a rectangular painting would still be rectangular after the transformation), for example, by adding more space around the figures or completing those figures that appear incomplete (even if this had been the artist's original intention) [16]. Generally speaking, the objective would be to adapt the work to a new style, with a preference for figures further away from the edges of the painting.

There are many instances of these enlargements, such as, for example, Portrait of a Man by Franciabigio (ca. 1510, enlarged between 1729 and 1752, Louvre, INV [Inventory Number] 517) or Christ and the Woman Taken in Adultery by Lorenzo Lotto (1527-1529, enlarged between 1683 and 1709, Louvre, INV 353) [16].

\section{Change of shape}

Change in style may imply a preference for a new format in paintings (round, oval, square, etc.): enlargement not only alters composition but also the painting's external format (Figure 2). In this case, as in the previous one, the aim is to adapt the work to a new painting style, but with changes that affect more noticeably perception of the work. An example of this kind of enlargement is The Union of Drawing and Colour by Guido Reni (ca. 1620-1625, Louvre, INV 534), enlarged in the second half of the seventeenth century: it changed from a rectangular format to a round one [15].

The Virgin and Child, Saint Elizabeth and Saint John the Baptist by Andrea del Sarto (ca. 1516, Louvre, INV 714) was a tondo on a wooden panel. Towards the end of the eighteenth century, it was transferred to canvas and enlarged to obtain an oval shape [20]. Another example is Holy Family and child St. John the Baptist by Juan de Juanes (ca. 1570, Lladró Museum [Tavernes Blanques, Spain]). This work originally had a rectangular format and was also transformed into an oval, probably in the nineteenth century [39]. 

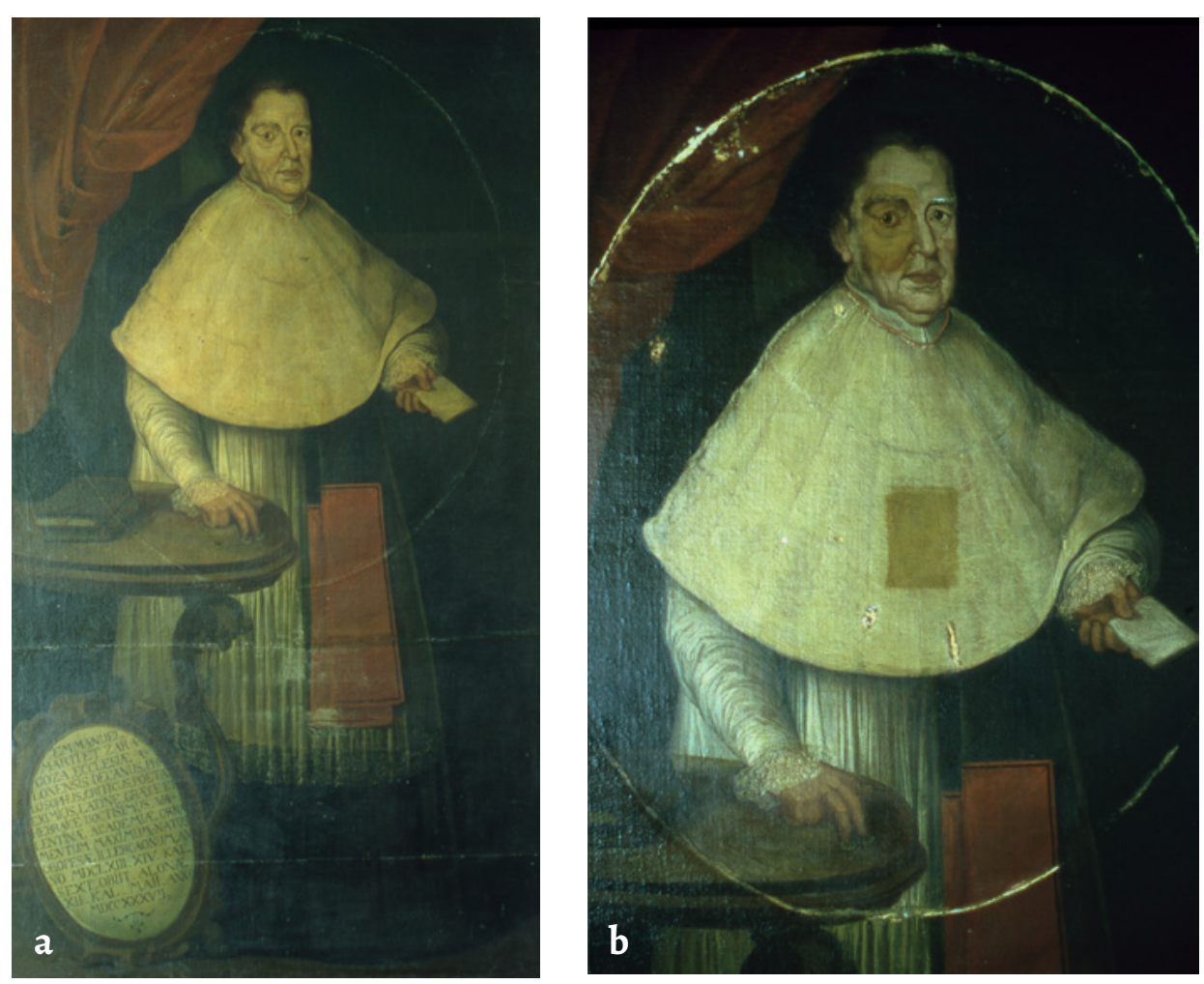

Figure 2. Manuel Martí y Zaragoza, attributed to José Vergara Gimeno (1730-1760, Universitat de València, INV UV102): $a$ ) Before restoration and b) during restoratio, where the filler between the original painting (central oval) and the additions can be seen. Credits: J. M. Barros García.

\section{Updating altarpieces}

Here, works are not independent paintings, but more complex structures such as altarpieces and polyptychs, which change their typology completely. These alterations can seek diverse aims, one of the most usual being to update a picture or the work in its entirety. Sometimes, it is a case of just adding a few pieces, but in the most extreme examples, the intervention can be combined with mutilation and addition and/or substitution of all kinds of elements in order to fashion a substantially different work from the original [40].

A well-known instance is the change which took place in Italy when polyptychs were adapted to a rectangular format (pala). An example of this kind of intervention is the San Domenico Altarpiece (ca. 1420, San Domenico di Fiesole) by Fra Angelico, modified by Lorenzo di Credi. Other well-known examples are the Badia Polyptych by Giotto (ca. 1300, Galleria degli Uffizi), transformed to pala by Jacopo del Corso in the fifteenth century or the Baroncelli Polyptych by Giotto (ca. 1334, Santa Croce, Florence), modernized in Ghirlandaio's studio [41]. Thanks to these transformations, the polyptychs gained a more realistic appearance and could continue to be used in religious worship.

\section{Adaptation to a new space and/or a new frame}

Moving a painting to a different place or modifications in the space where it was on display were habitual reasons for enlargement (or sometimes mutilation). These modifications were more usual in Europe from the seventeenth century on, when great palaces and countless buildings, both civil and religious, were built, and many others were transformed [9].

A late example of this kind of intervention is the tapestry cartoon Hunter Loading his Rifle by Francisco de Goya (1775, Prado, INV Poo5539), joined in 1933 to another tapestry cartoon painted by Matías Téllez in 1773. The aim here seems to have been the need to broaden Goya's work (originally $50 \mathrm{~cm}$ wide) in order to adapt it to a new space [42].

In some cases, a work is enlarged to adapt it to a new frame, which often, although not always, is connected with a change in location. Sometimes the aim is to reuse an existing frame, so the painting's dimensions are modified. In other cases, the painting is modified in order to insert it into a new altarpiece [40].

In the Universitat de València's (University of Valencia) chapel, there is a painting on panel by Nicolás Falcó, The Virgin of Wisdom (1516, INV UV11), which gives the chapel its name. This painting, from a sixteenth-century altarpiece, was enlarged along the bottom in order to adapt it to a new and bigger altarpiece in the eighteenth century [43-45].

This type of intervention, like those described in the following sections, does not necessarily imply the painting's modernization. Regarding the enlargement of The Virgin of Wisdom, the aim was not to change the painting's style; the sole purpose of the addition was to adjust the dimensions of the panel to a new altarpiece.

\section{Completing mutilated paintings}

The enlargement of a painting which has lost part of its 


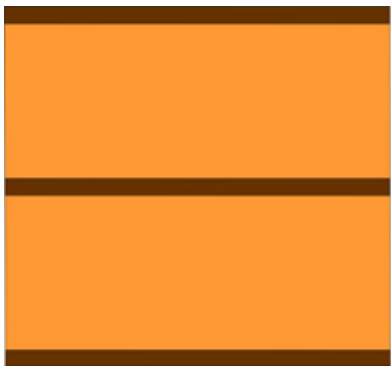

a

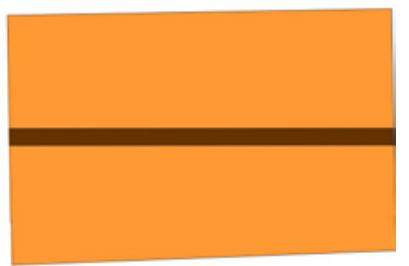

b

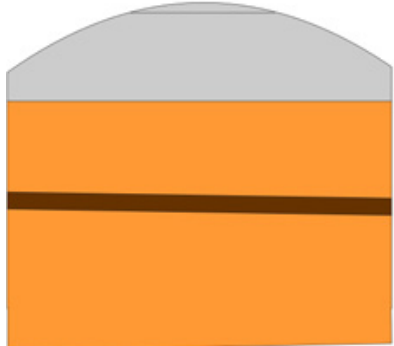

C

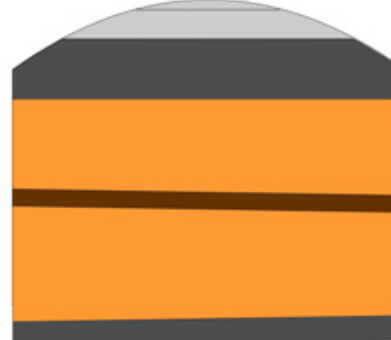

d

Figure 3. Diagram showing the evolution of the support on the painting Adoration of the Shepherds (sixteenth century, Valencia Cathedral Museum): $a$ ) the work's original shape; b) mutilation of the support; c) enlargement of the upper part; d) new crossbars. Credits: J. M. Barros García.

support (due either to accidental causes or intentional mutilation) aims at trying to restore adequate proportions to the work, thereby recovering part of its legibility. In some cases, the intervention can almost be considered a reintegration, although in many other instances the enlargement's real aim is not to recover the work's original dimensions and format but, instead, to fashion the work with a new appearance.

An example is The Virgin and Child before a Firescreen by a follower of Robert Campin (ca. 1440, The National Gallery, INV NG2609), enlarged in the nineteenth century [46]. On the other hand, the Adoration of the Shepherds, attributed to Felipe Pablo de San Leocadio (sixteenth century, Cathedral Museum, Valencia), was cut along the top and bottom, probably due to damage by termites. It was repaired between the seventeenth and eighteenth centuries, by adding new boards on the upper part (Figure 3). In this case, the aim was not to reconstruct the painting's original size and format (rectangular) but rather to complete the portion of the sky and, at the same time, modify the work's shape (Figure 4) [12].

\section{Changes in iconography}

Occasionally, the enlargement is carried out in order to add new iconographic elements (Figure 5), modifying the work's meaning, and sometimes even its function and title. When a painting changed ownership, it was common practice to add the new owner's coat of arms or inscriptions relating to him. These actions were also carried out when the owner gained a new social status or a new political or religious position. At times, the support had to be enlarged to create enough space to include all the new information.

An example is Christ Appearing to His Mother by Guido Reni (Museum of Fine Arts of Nancy, INV 15). This work, painted at the beginning of the seventeenth century, was enlarged to include, among other elements, the coat of arms of its new owner, cardinal Charles de Lorraine [47-48].

Another example is a sixteenth-century painting representing the Virgin and Child (Convento de los Padres Capuchinos de El Pardo, Madrid) which was inserted into a new pictorial composition by Alonso del Arco in 1693, resulting in a new painting: Philip III Praying before Our Mother of Consolation, where the king appears praying in

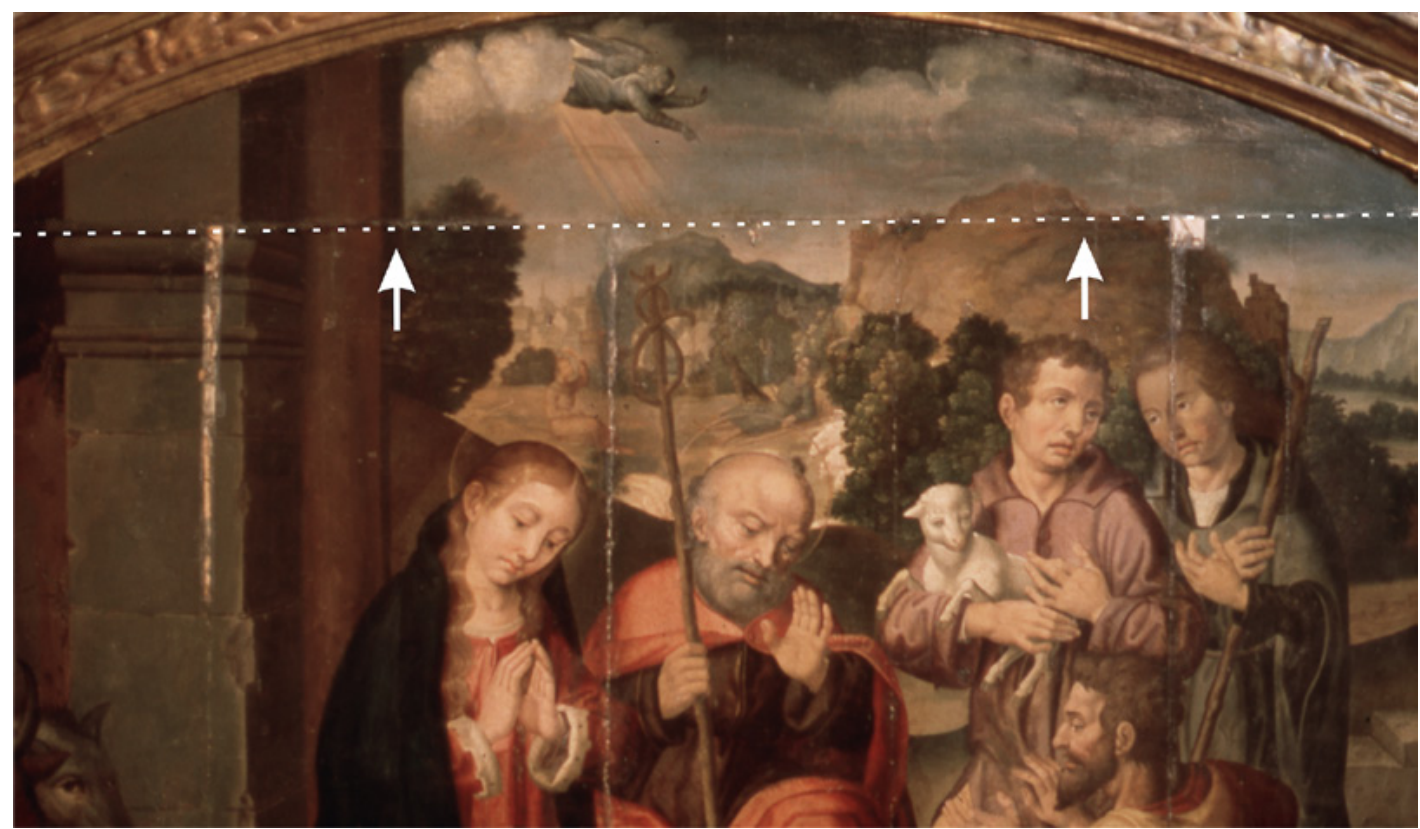

Figure 4. Upper part of the Adoration of the Shepherds. The line marks the limit with the addition to the upper part. Credits: J. M. Barros García. 


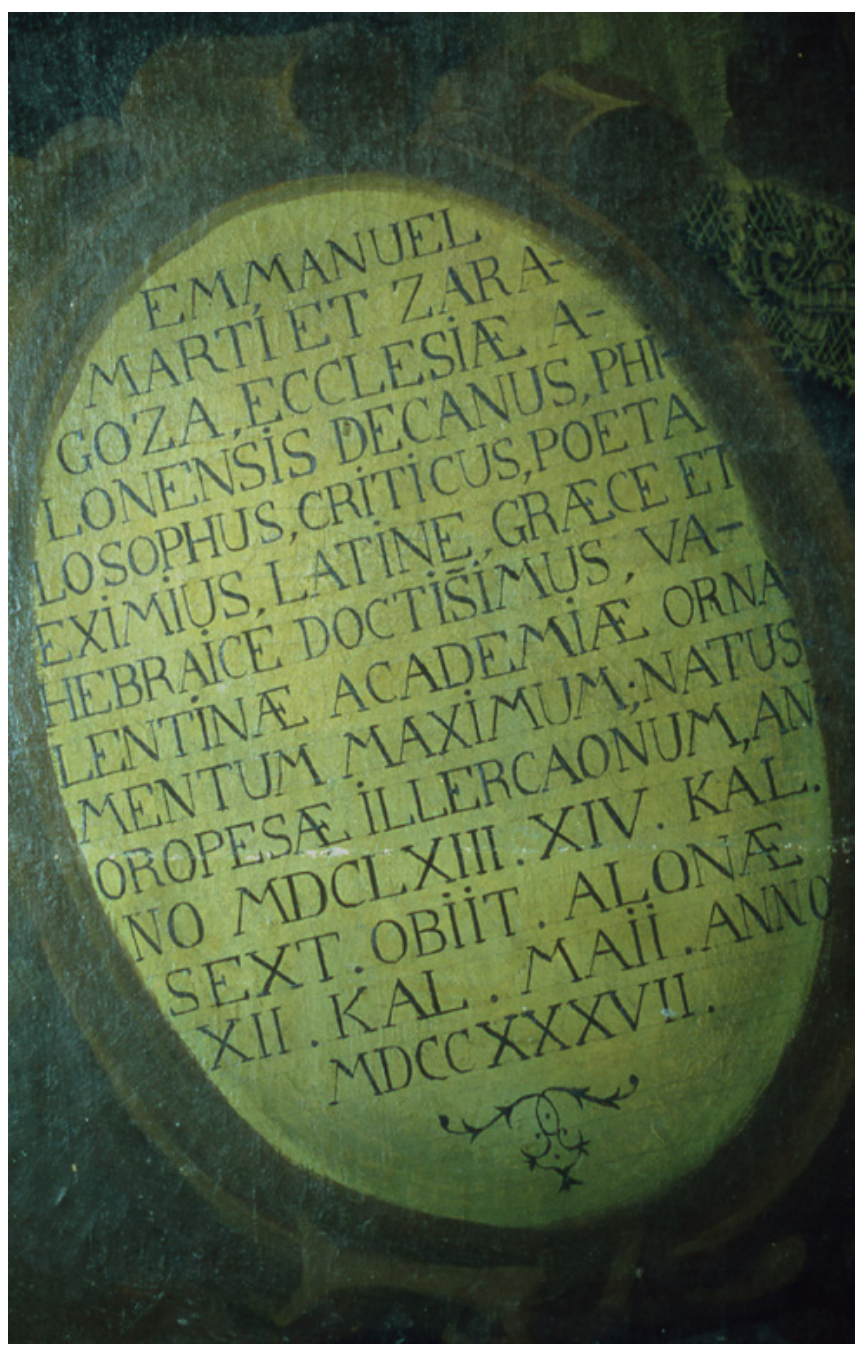

Figure 5. Detail of Figure 2a. Targe with text, included in the addition. Credits: J. M. Barros García.

presence of the older image. This is a clear case of change in iconography by means of a material assemblage, which includes a painting within a newer one, consequently enlarging the older painting [49].

\section{Enlargement in order to create independent works}

Enlargement can also serve to create an autonomous work. It is a question of separating the painting from an architectural context, a series of paintings or an altarpiece. Sometimes paintings were inserted in architectural mouldings, as part of an assemblage of decorative and symbolic elements. Once separated from the mouldings, if necessary, they were transformed into a rectangular format. In this way, a painting once linked to an architectural structure and an iconographic program, becomes an independent work of art.

Two well-known examples are Les Attributs des Arts and Les Attributs de la Musique by Chardin (1765, Louvre, INV 3199 and 3200), created for the upper part of some doors at the château royal (royal castle) de Choisy (Ile-de-France). At the end of the eighteenth century, they were removed from their original location and enlarged [16].

A Man Embracing a Woman by Dosso Dossi (ca. 1524, The National Gallery, INV NG1234) is a special case. It is a fragment of a ceiling tondo on poplar which was enlarged later on, with additional inserts to regularise its shape [50].

\section{Grouping paintings together}

Another reason for enlarging paintings is the exact opposite of that illustrated in the previous section: in this case, the enlargement is carried out in order to unify the format of works of different sizes so they can be exhibited together, as a pair or a series. Thanks to the additions, the paintings can be linked to others with which they had no previous connection at all. This kind of intervention clearly shows that, sometimes, a painting's links with other elements of the assemblage may be more important than the work's own characteristics.

\section{Creating pendants}

In this type of intervention, the aim of the enlargement is to modify a work so that its size and shape are the same as those of another painting. In this way, the works can become a pair, side by side on the wall or, opposite each other in the same room. A well-known example is Virgin and Child by Francesco Gessi (ca. 1624, Louvre, INV 523) which was enlarged in 1754. It went from an oval shape to a circle in order to form a pendant with the painting which had already been enlarged in the previous century, The Union of Drawing and Colour by Guido Reni (ca. 1620-1625, Louvre, INV 534).

The Good Shepherd by Murillo (ca. 1660, Museo del Prado, INV 962) was enlarged in the first half of the eighteenth century to form a pair with Infant Saint John the Baptist (ca. 1670, Museo del Prado, INV 963) by the same painter [49]. Lastly, another very interesting example is Children Playing Dice by Pedro Núñez de Villavicencio (ca. 1686, Prado, INV 1235) possibly enlarged by Luca Giordano, to link it to his own painting Boys Fighting (ca. 1694, Prado, INV 3939) at the Zarzuela Palace [51].

\section{Forming a series of paintings}

As with the previous section, a group of paintings with diverse formats and dimensions can be enlarged in order to achieve a more homogeneous format. The difference being that instead of creating a pendant, a series of paintings, comprising numerous works, would originate. Sometimes a painting is enlarged to adapt it to an already existing series, at other times, enlargements might be carried out on several paintings in order to form a completely new series, one which had not existed previously. An example of the first case is the painting on canvas Saint Vincent Ferrer (seventeenth century, Universitat de València, INV UV8). This work was enlarged in order to adapt it to the format of the other paintings in the chapel where it can be found [43] (images of the Universitat de València's entire collection of paintings can be accessed on the website https://colecciones.uv.es/portal.php). 


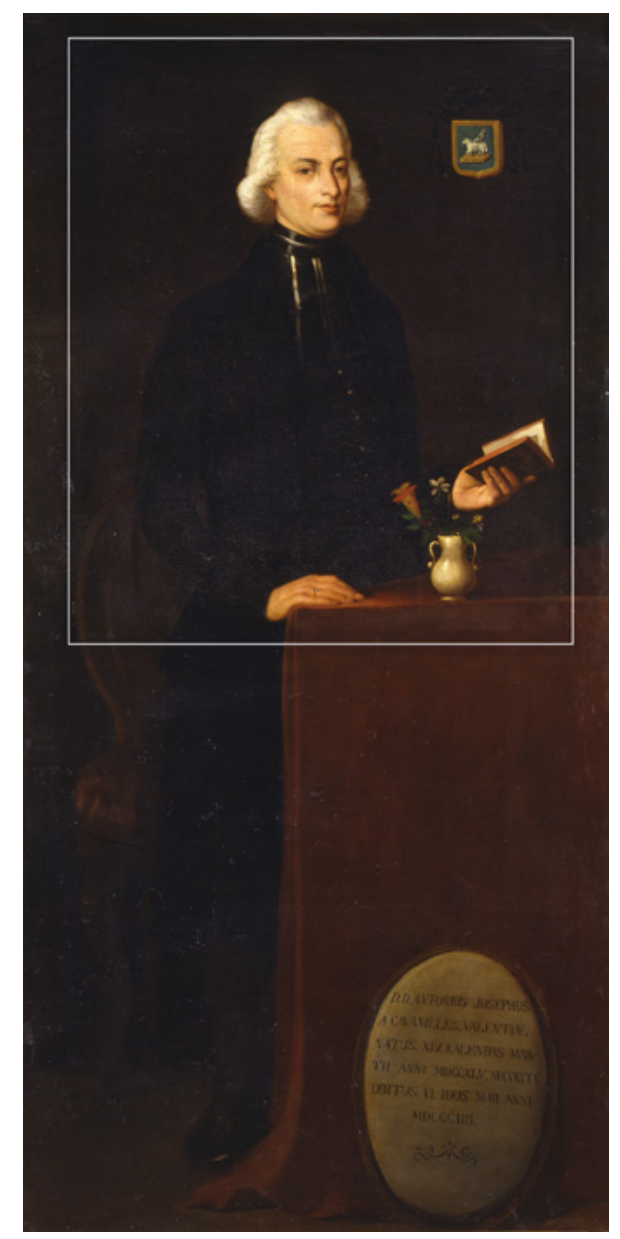

Figure 6. Antonio José Cavanilles painted by the circle of Mariano Salvador Maella (1775-1780, Universitat de València, INV UV97). The rectangle in the centre marks the boundary of the original painting. Credits: J. M. Barros García.

An example of adaptation carried out on many paintings on canvas, in order to create a series, can be found at the Paraninfo (Main Hall) of the Universitat de València. Here a group of 42 portraits painted on canvas (mostly during the eighteenth and nineteenth centuries), represent historical figures linked to the university [52]. The older paintings have extremely diverse formats due to the fact that they come from different places. These works were unified by giving them all a rectangular format, thus creating a more homogeneous series [44] (Figures 6-8). More recent paintings, carried out in the twentieth and twenty-first centuries, were painted on a rectangular-shaped support.

It must be pointed out that despite having been enlarged, each painting has, to a large extent, maintained its pictorial style, perhaps rather surprisingly, given that the collection encompasses works from the seventeenth through to the twenty-first centuries (the series has recently been added to). The numerous overpaints present on many of the paintings were, indeed, carried out in order to disguise damages to the works, not to modernize them.

As mentioned above, anthropology has provided new points of view to better understand the concept of aesthetics.

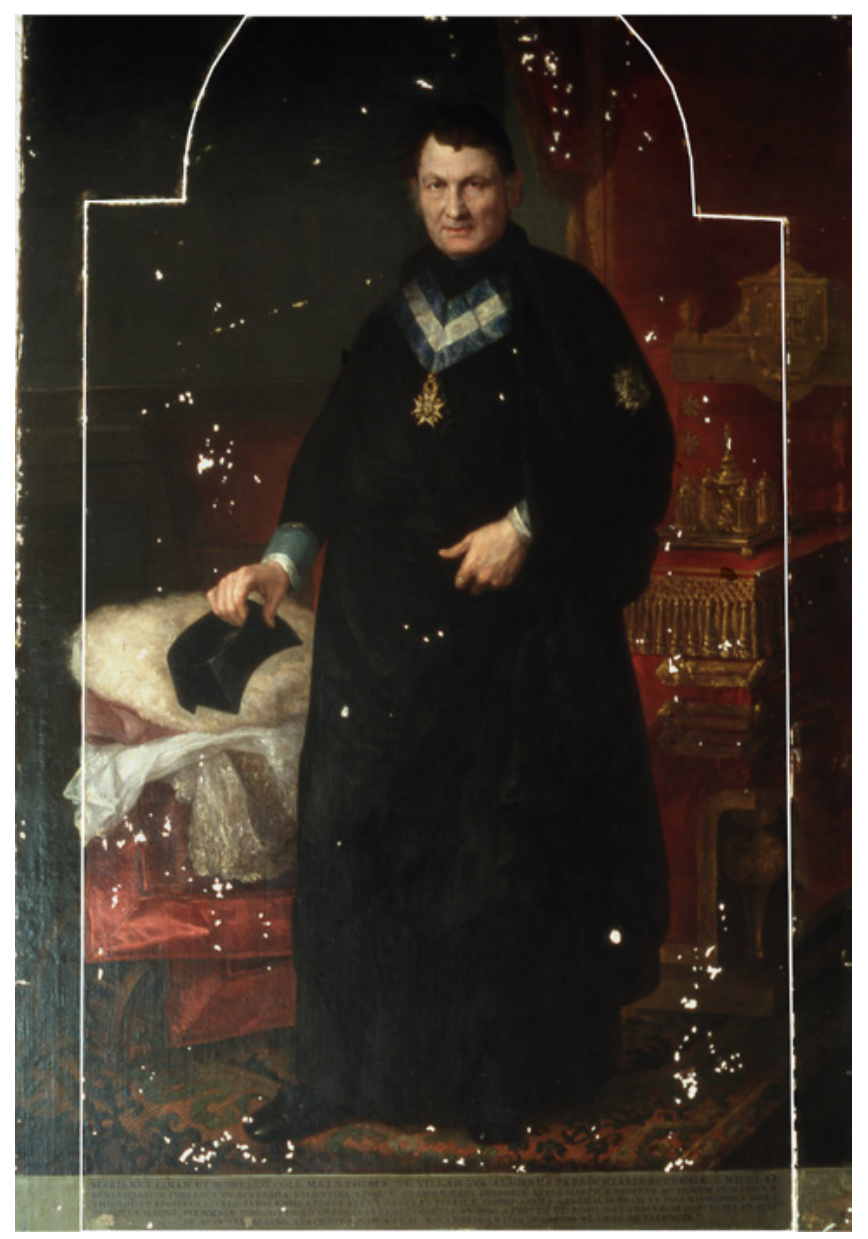

Figure 7. Mariano Liñán y Morelló by Bernardo López Piquer (1840, Universitat de València, INV UV91). The white line shows the boundary of the original painting. Credits: J. M. Barros García.

It is no longer understood merely from the point of view of beauty, although this term is frequently used when analysing the aesthetic value of cultural heritage [36, 53]. Regarding an enlarged painting, it is interesting to verify whether the work's formal characteristics (in its present state, additions included) are the most adequate in order for the painting to carry out its functions within a social assemblage. A close look at the Universitat de València's Paraninfo paintings, shows that many enlargements were not carried out very well. However, it is precisely the additions that enable the series of portraits to exist as such, instead of as a group of individual paintings with hardly any relationship linking them together.

The Paraninfo is the most important ceremonial hall in the Universitat de València, and the portraits are essential elements in the academic rituals carried out in that hall. The paintings are also actors [32] in that particular assemblage and they can perform as such thanks to the unification of their format, achieved through enlarging most of the works. Unification has permitted works of diverse aesthetic characteristics to be linked together, generating a coherent series. 

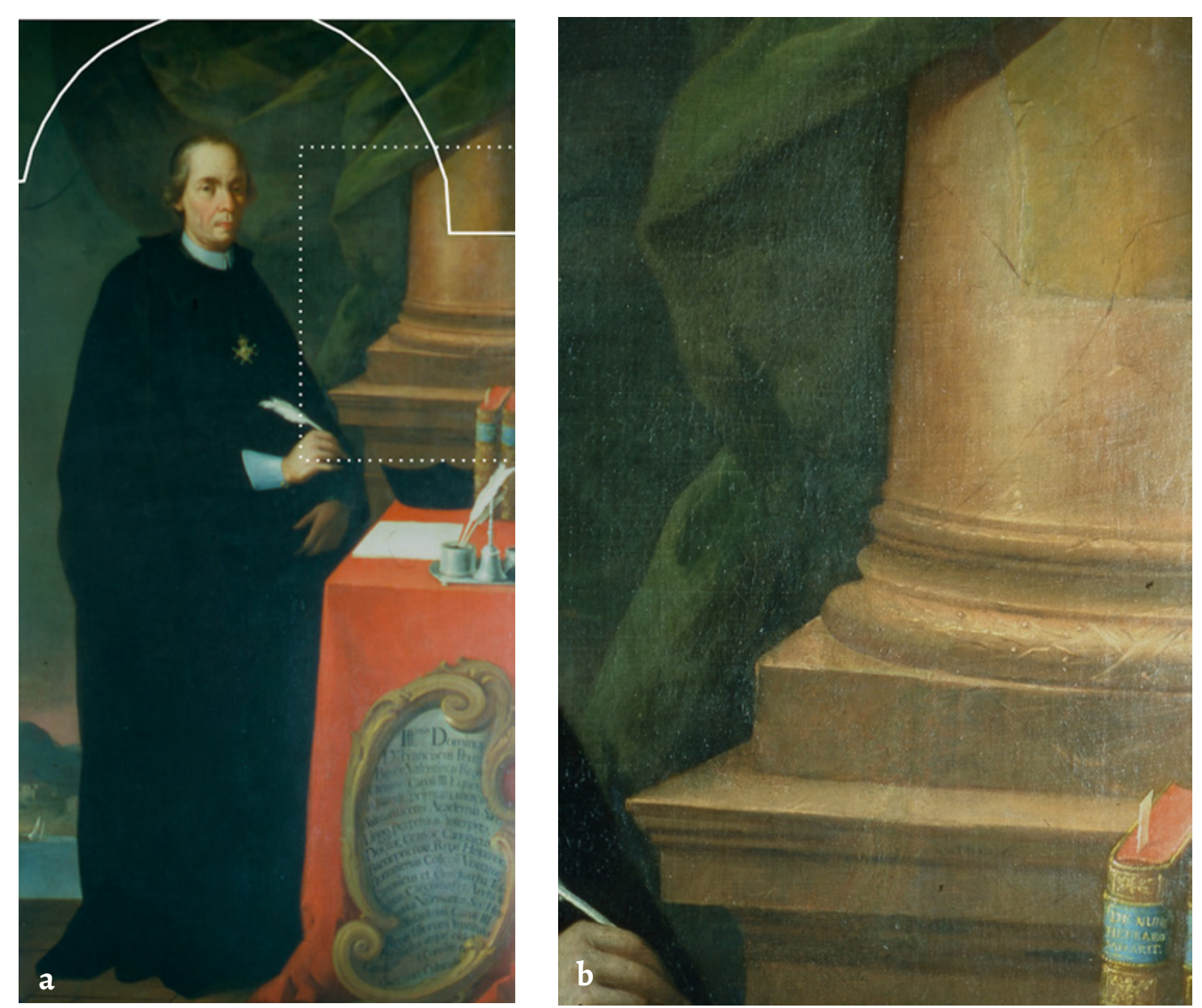

Figure 8. Francisco Pérez Bayer, attributed to Vicente López (1750-1800, Universitat de València, INV UV110): a) The white line shows the boundary with the additions; $b$ ) the difference between the colour of the original painting and additions can be seen. Credits: J. M. Barros García.

\section{Conclusions}

Although the enlargement of paintings was common practice from the seventeenth century up until the end of the nineteenth century, and numerous examples exist, it remains an insufficiently studied topic. When a conservator is faced with the problem of restoring an enlarged painting, lack of information is a significant difficulty. This paper puts forward a classification of different reasons why a painting is enlarged, although the underlying reason for this type of intervention is usually the need to establish new relationships between a painting and other elements (people and/or artefacts) within changing contexts. In other words, a painting is enlarged in order to adapt it to the functions and values it must have in a new social assemblage.

The classification we put forward in this paper includes the following categories: updating pictures (adapting them to a new artistic or decorative style), adaptation to a new space and/or a new frame, completing mutilated paintings, changes in iconography, enlargement in order to create independent works, and grouping paintings together (creating pendants or forming a series of paintings).

This classification can prove useful when studying enlargements and also in decision-making (whether to preserve or not the additions). When the work is to be restored, the adequacy of additions present must be evaluated, bearing in mind the new values and functions the work will have in its current assemblage. If the reason the work was originally enlarged (for example, adaptation to a new space) still makes sense (if the work is to remain in the same location), this could be a good argument in favour of preserving the additions. Obviously, many other factors should also be borne in mind, such as, for example, the work's state of conservation and, especially whether the additions could have a negative effect on its preservation.

However, more studies are necessary in order to complete the classification proposed in this paper: analysing the work's evolution through different assemblages and the changes undergone by the work's values in each new context. Likewise, it is important to have more information made available regarding enlargement techniques and different solutions adopted in the exhibition of these paintings at present. An interesting possibility would be the creation of a database of enlarged paintings, including, for example, changes in size and shape, changes of location, reasons for enlargement and the decisions made regarding additions (removed, hidden or shown). In this way, the information 
could serve as a model for other restoration projects of enlarged paintings, and thus facilitate decision-making.

Another matter which merits more attention is the possibility of applying Assemblage Theory and ActorNetwork Theory to the conservation of cultural heritage, thereby enabling a more comprehensive understanding of the relationships established between those artefacts to be conserved and any other significant element of social reality.

\section{REFERENCES}

1. Dardes, K.; Rothe, A. (eds.), The Structural Conservation of Panel Paintings. Proceedings of a Symposium at the J. Paul Getty Museum, 24-28 April 1995, Getty Conservation Institute, Los Angeles (1998), http://hdl.handle.net/10020/gci_pubs/panelpaintings (accessed 2020-09-07).

2. Bailly, N., Inventaire des Tableaux du Roy [with additions and annotations by F. Engerand], E. Leroux, Paris ([1709-1710] 1899), http://bibliotheque-numerique.inha.fr/idurl/1/4727 (accessed 2020-09-07).

3. Vindry, G., Restaurations et modifications des peintures dans les collections françaises du XV' siècle à la fin du XVIII siècle, $\mathrm{PhD}$ dissertation, Ecole du Louvre, Paris (1969).

4. Étienne, N., The Restoration of Paintings in Paris, 1750-1815, Translated by S. Grevet, Getty Conservation Institute, Los Angeles (2017).

5. Chiarini, M.; Ciatti, M.; Padovani, S. (eds.), Raffaello a Pitti 'La Madonna del Baldacchino', Centro Di, Florence (1991).

6. Ciatti, M.; Padovani, S. (eds.), La Pala Dei del Rosso Fiorentino a Pitti: Storia e Restauro, Edifir, Florence (2005).

7. Morán Turina, J. M.; Checa Cremades, F., El Coleccionismo en España: de la Cámara de Maravillas a la Galería de Pinturas, Cátedra, Madrid (1985).

8. Garrido, M. C.; Dávila, M. T.; Dávila, R., 'Las Hilanderas: estudio técnico y restauración', Boletín del Museo del Prado 7 (1986) 145-165, https://www.museodelprado.es/aprende/ boletin/las-hilanderas-estudio-tecnico-y-restauracion/ f8f20937-0544-47c4-966a-ad6eccbf4f7c (accessed 2020-09-07).

9. Ruiz de Lacanal, M. D., 'El gran coleccionista Felipe IV y grandes conservadores y restauradores de su tiempo: Velázquez, Carducho y Murillo', Atrio 8 (1995) 105-111, https:// www.upo.es/revistas/index.php/atrio/article/view/3125/2459 (accessed 2020-09-07).

10. García-Máiquez, J.; Jover de Celis, M., 'La manipulación del formato original de las obras: un ejemplo de la aportación de los estudios técnicos en el conocimiento de la idea inicial del artista', in Investigación en Conservación y Restauración: II Congreso del Grupo Español del IIC, Museu Nacional d'Art de Catalunya, Barcelona (2005) 24-, http://ge-iic.com/ files/2congresoGE/La_manipulacion_del_formato_original. pdf (accessed 2020-09-05).

11. Martínez Justicia, M. J., Historia y Teoría de la Conservación y Restauración Artística, Tecnos, Madrid (2008).

12. Barros García, J. M., Imágenes y Sedimentos. La Limpieza en la Conservación del Patrimonio Pictórico, Institució Alfons el Magnànim, Valencia (2005).

13. López Bonilla, A. I., Las ampliaciones de formato en pintura de caballete, $\mathrm{PhD}$ dissertation, Universitat Politècnica de València, Valencia (2017), https://riunet.upv.es/

handle/10251/30246 (accessed 2020-09-05).

14. Martin, E.; Bret, J., 'Le changement par le peintre du format de son oeuvre: étude technique et typologie des agrandissements', in 13th Triennial Meeting ICOM-CC, James \& James, London (2002) 439-445.

15. Conti, A., A History of the Restoration and Conservation of Works of Art, Translated by H. Glanville, Butterworth-Heinemann, Burlington (2007, originally published 1988).

16. Bergeon, S.; Émile-Mâle, G.; Faillant-Dumas, L., Restauration des Peintures, Édition de la Réunion des Musées Nationaux, Paris (1980).

17. Bomford, D.; Brough, J.; Roy, A., 'Three panels from Perugino's Certosa di Pavia Altarpiece', National Gallery Technical Bulletin 4 (1980) 3-31, https://www.nationalgallery.org.uk/research/ technical-bulletin/three-panels-from-peruginos-certosa-dipavia-altarpiece (accessed 2020-09-04).

18. Barros García, J. M., 'Re-evaluating the roles of the cleaning process in the conservation of paintings', Ge-conservación 7 (2015) 14-23, https://doi.org/10.37558/gec.v7io.210.

19. Brandi, C., Theory of Restoration, ed. G. Basile, Translated by C. Rockwell, Nardini Editore and Istituto Centrale per il Restauro, Florence (2005, originally published 1977).

20. Bergeon, S., Science et Patience ou la Restauration des Peintures, Éditions de la Réunion des Musées Nationaux, Paris (1990).

21. Muñoz Viñas, S., Contemporary Theory of Conservation, Elsevier Butterworth-Heinemann, Oxford (2005).

22. Muñoz Viñas, S., 'Pertinencia de la Teoria del Restauro', in Interim Meeting on Conservation Training. Jornada Internacional "A 100 Anni della Nascita di Cesare Brandi", ed. P. Roig Picazo, Universitat Politècnica de València, Valencia (2007) 121-133.

23. Muñoz Viñas, S., "Who is afraid of Cesare Brandi?" Personal reflections on the Teoria del Restauro', CeROArt HS (2015), http://journals.openedition.org/ceroart/4653 (accessed 202009-08).

24. Baxandall, M., Painting and Experience in Fifteenth Century Italy, Oxford University Press, Oxford ([1972] 1988).

25. Duncan, C., Civilizing Rituals. Inside Public Art Museums, Routledge, London (1995).

26. Marcus, G. E.; Saka, E., 'Assemblage', Theory, Culture \& Society 23(2-3) (2006) 101-109, https://doi. org/10.1177/0263276406062573.

27. DeLanda, M., A New Philosophy of Society: Assemblage Theory and Social Complexity, Continuum, New York (2006).

28. DeLanda, M., Assemblage Theory, Edinburgh University Press, Edinburgh (2016).

29. Müller, M.; Schurr, C., 'Assemblage thinking and actornetwork theory: conjunctions, disjunctions, crossfertilisations', Transactions of the Institute of British Geographers 41(3) (2016) 217-229, https://doi.org/10.1111/tran.12117.

30. Deleuze, G.; Guattari, F., A Thousand Plateaus, Translated by B. Massumi, University of Minnesota Press, Minneapolis (2005, originally published 1987).

31. Müller, M., 'Assemblages and actor-networks: rethinking socio-material power, politics and space', Geography Compass 9(1) (2015) 27-41, https://doi.org/10.1111/gec3.12192.

32. Latour, B., Reassembling the Social, Oxford University Press, Oxford (2005).

33. Law, J., After Method, Routledge, London (2004). 


\section{A. I. López Bonilla, J. M. Barros García, S. Martín Rey}

34. Tuddenham, D. B., 'Ship finds and their management as actor network', Journal of Maritime Archaeology 7 (2012) 231-243, https://doi.org/10.1007/s11457-012-9095-8.

35. Yadollahi, S., 'Prospects of applying assemblage thinking for further methodological developments in urban conservation planning', The Historic Environment: Policy \& Practice 8(4) (2017) 355-371, https://doi.org/10.1080/17567505.2017.1399977.

36. de la Torre, M. (ed.), Assessing the Values of Cultural Heritage, Getty Conservation Institute, Los Angeles (2002), https:// www.getty.edu/conservation/publications_resources/pdf_ publications/pdf/assessing.pdf (accessed 2020-09-11).

37. Gell, A., 'The technology of enchantment and the enchantment of technology', in The Art of Anthropology. Essays and Diagrams, ed. E. Hirsch, Berg, Oxford (2006) 159-186.

38. Gell, A., Art and Agency, Clarendon Press, Oxford (1998).

39. Puig Sanchis, I., 'Sobre dos pinturas de Juan de Juanes en las colecciones Lladró y Laia-Bosch', BSAA arte: Boletín del Seminario de Estudios de Arte 79 (2013) 69-82, https://dialnet.unirioja.es/ descarga/articulo/4549840.pdf (accessed 2020-09-10).

40. García Enguix, V., Transformaciones y cambios de contexto en los retablos. El caso de Xátiva, $\mathrm{PhD}$ dissertation, Universitat Politècnica de València, Valencia (2017), https://riunet.upv.es/ handle/10251/90563 (accessed 2020-09-05).

41. Baldini, U., Teoria del Restauro e Unità di Metodologia, Vol. I, Nardini, Florence (1982).

42. Prado, Museo Nacional del, Restauración: Cazador cargando su escopeta de Francisco de Goya [video] (2014), https://www. youtube.com $/$ watch?time_continue $=517 \& \mathrm{v}=$ g7JSzzmZL70 (accessed 2020-09-07).

43. Benito Goerlich, D., La Capilla de la Universitat de València, Universitat de València, Valencia (1990).

44. Barros García, J. M., 'La imagen humillada', in Herencia Pintada. Obras Pictóricas Restauradas de la Universitat de València, ed. D. Benito Goerlich, Universitat de València y Fundació General de la Universitat de València, Valencia (2002) 17-37.

45. Benito Goerlich, D.; Besó Ros, A. (eds.), La Tabla de la Virgen de la Sapiencia de la Universitat de València, Universitat de València, Valencia (2019).

46. Campbell, L.; Bomford, D.; Roy, A.; White, R., 'The Virgin and Child before a firescreen: history, examination and treatment', National Gallery Technical Bulletin 15 (1994) 2035, http://www.nationalgallery.org.uk/technical-bulletin/ campbell_bomford_roy_white1994 (accessed 2020-09-10).
47. Gelly, C., Nancy, Musée des Beaux-Arts: Peintures Italiennes et Espagnoles, XIVe-XIXe Siècle, Editions IAC, Paris (2006).

48. Bergeon, S.; Curie, P., Peinture et Dessin. Vocabulaire Typologique et Technique. Vol. 1, Éditions du Patrimoine, Paris (2009).

49. Macarrón Miguel, A. M., Historia de la Conservación y la Restauración, Tecnos, Madrid (1995).

50. Braham, A.; Dunkerton, J., 'Fragments of a ceiling decoration by Dosso Dossi', National Gallery Technical Bulletin 5 (1981) 2737, https:/www.nationalgallery.org.uk/technical-bulletin/ braham_dunkerton1981 (accessed 2020-09-10).

51. Alba, L.; Jover de Celis, M., 'Niños jugando a los dados de Pedro Núñez de Villavicencio. Historia de una obra a través de su radiografía', Ge-Conservación o (2009) 47-61, https://doi. org/10.37558/gec.voio.63.

52. Benito Goerlich, D.; Mora Castro, A. J., El Paraninfo de la Universitat de València y sus Personajes Retratados: Testimonio de Saber, Historia y Ceremonia, Universitat de València, Valencia (2014).

53. Avrami, E.; Mason, R.; de la Torre, M. (eds.), Values and Heritage Conservation, Getty Conservation Institute, Los Angeles (2000), https://www.getty.edu/conservation/ publications_resources/pdf_publications/pdf/valuesrpt.pdf (accessed 2020-09-10).

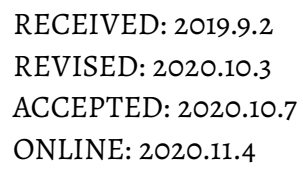

\section{(c) (1)(3) $(9)$}

This work is licensed under the Creative Commons Attribution-NonCommercial-NoDerivatives 4.0 International License. To view a copy of this license, visit http://creativecommons.org/licenses/by-nc-nd/4.o/deed.en. 